\title{
Desulfovibrio paquesii sp. nov., a hydrogenotrophic sulfate-reducing bacterium isolated from a synthesis-gas-fed bioreactor treating zinc- and sulfate-rich wastewater
}

Correspondence

Alfons J. M. Stams

fons.stams@wur.nl

\author{
Bernd H. G. W. van Houten, ${ }^{1}$ † Roel J. W. Meulepas, ${ }^{1}$ Wim van Doesburg, ${ }^{1}$ \\ Hauke Smidt, ${ }^{1}$ Gerard Muyzer ${ }^{2}$ and Alfons J. M. Stams ${ }^{1}$
${ }^{1}$ Laboratory of Microbiology, Wageningen University, Dreijenplein 10, Gebouw 316, 6703 HB Wageningen, The Netherlands \\ ${ }^{2}$ Department of Biotechnology, Delft University of Technology, Julianalaan 67, 2628 BC Delft, \\ The Netherlands
}

\begin{abstract}
A hydrogenotrophic, sulfate-reducing bacterium, designated strain $\mathrm{SB}^{\top}$, was isolated from sulfidogenic sludge of a full-scale synthesis-gas-fed bioreactor used to remediate wastewater from a zinc smelter. Strain $\mathrm{SB} 1^{\top}$ was found to be an abundant micro-organism in the sludge at the time of isolation. Hydrogen, formate, pyruvate, lactate, malate, fumarate, succinate, ethanol and glycerol served as electron donors for sulfate reduction. Organic substrates were incompletely oxidized to acetate. 16S rRNA gene sequence analysis showed that the closest recognized relative to strain $\mathrm{SB} 1^{\top}$ was Desulfovibrio gigas $\mathrm{DSM} 1382^{\top}$ ( $97.5 \%$ similarity). The $\mathrm{G}+\mathrm{C}$ content of the genomic DNA of strain $\mathrm{SB} 1^{\top}$ was $62.2 \mathrm{~mol} \%$, comparable with that of Desulfovibrio gigas DSM $1382^{\top}\left(60.2\right.$ mol\%). However, the level of DNA-DNA relatedness between strain SB1 ${ }^{\top}$ and Desulfovibrio gigas DSM $1382^{\top}$ was only $56.0 \%$, indicating that the two strains are not related at the species level. Strain $\mathrm{SB} 1^{\top}$ could also be differentiated from Desulfovibrio gigas based on phenotypic characteristics, such as major cellular fatty acid composition (anteiso- $\mathrm{C}_{15: 0}$, iso$\mathrm{C}_{14: 0}$ and $\mathrm{C}_{18: 1}$ cis 9 ) and substrate utilization. Strain $\mathrm{SB} 1^{\top}$ is therefore considered to represent a novel species of the genus Desulfovibrio, for which the name Desulfovibrio paquesii sp. nov. is proposed. The type strain is $\mathrm{SB} 1^{\top}\left(=\mathrm{DSM} 16681^{\top}=\mathrm{JCM} 14635^{\top}\right)$.
\end{abstract}

Sulfate- and metal-rich wastewaters that are low in organic carbon are produced as a result of several industrial processes and pose a large environmental problem (Lens et al., 1998; Johnson, 2000). Synthesis-gas-fed sulfatereducing bioreactors have been shown to be suitable systems to remediate these types of wastewater (Boonstra et al., 1999; van Houten et al., 2006). In a previous study, the communities of two synthesis-gas-fed sulfate-reducing THIOPAQ bioreactors were found to be dominated by heterotrophic sulfate-reducing bacteria belonging to the

tPresent address: Institute of Rural Sciences, Aberystwyth University, Llanbadarn Fawr, Aberystwyth SY23 3AL, UK.

Abbreviations: DGGE, denaturing gradient gel electrophoresis; rep-PCR, repetitive enterobacterial palindromic $P C R$.

The GenBank/EMBL/DDBJ accession numbers for the 16S rRNA gene sequences of strain $\mathrm{SB} 1^{\top}$ and Desulfovibrio gigas DSM $1382^{\top}$ are AY726757 and DQ447183, respectively.

A rep-PCR pattern comparison of strain $\mathrm{SB} 1^{\top}$ and Desulfovibrio strains L3 and L7 is available as supplementary material with the online version of this paper. genera Desulfovibrio and Desulfomicrobium (van Houten et al., 2006). In order to perform growth kinetic and competition studies (van Houten, 2006), micro-organisms representing different trophic groups were isolated from these synthesis-gas-fed bioreactors.

A sulfate-reducing bacterium, designated strain $\mathrm{SB}^{\mathrm{T}}$, was isolated from the sulfidogenic sludge of a full-scale THIOPAQ gas lift bioreactor, as described previously (van Houten et al., 2006). This bioreactor, used for the remediation of wastewater from a zinc smelter (BudelDorplein, The Netherlands), was fed with hydrogen-rich synthesis gas and was operated at a temperature of 30$35{ }^{\circ} \mathrm{C}$ (van Houten et al., 2006).

Sludge taken from the recycled material was crushed as described by Oude Elferink et al. (1995), serially diluted in defined liquid medium (Stams et al., 1993) supplemented with sulfate $(20 \mathrm{mM})$, acetate $(4 \mathrm{mM})$ and an $\mathrm{H}_{2} / \mathrm{CO}_{2}$ gasphase (ratio $4: 1$, pressure $1.7 \mathrm{kPa}$ ), and incubated at $30{ }^{\circ} \mathrm{C}$. Strain $\mathrm{SB} 1^{\mathrm{T}}$ was obtained from the highest dilution showing growth $\left(10^{8}\right)$, which contained micro-organisms 
with two distinct cell morphologies. This dilution was serially diluted in liquid medium and after incubation the highest dilution showing growth was serially diluted by using the agar roll-tube method (Hungate, 1969). A single well-separated colony was taken and serially diluted in liquid medium. The highest dilution showing growth was a pure culture, and this was designated strain $\mathrm{SB}^{\mathrm{T}}$. The morphology of this micro-organism was the dominant one observed in the original highest dilution. Purity was confirmed by microscopic observation, from uniform colony formation in agar tubes and by testing for anaerobic contaminants on Wilkins-Chalgren anaerobe broth.

Cells of strain $\mathrm{SB1}^{\mathrm{T}}$ were vibrio- to spiral-shaped $(1 \times 5-$ $8 \mu \mathrm{m}$ ), motile and appeared singly or in chains of up to eight cells. Strain $\mathrm{SB1}^{\mathrm{T}}$ was desulfoviridin-positive and stained Gram-negative. Phase-contrast microscopy showed refractive structures, but spores were never observed. In solid medium the strain produced lens-shaped colonies.

For phylogenetic analysis, total DNA was extracted as described by Oude Elferink et al. (1997). 16S rRNA gene sequence analysis and denaturing gradient gel electrophoresis (DGGE) analysis were performed according to Roest $e t$ al. (2005). Two different $16 \mathrm{~S}$ rRNA gene sequences were found for strain $\mathrm{SB1}^{\mathrm{T}}$, showing a single base pair difference at Escherichia coli position 1326. DGGE analysis with a primer pair amplifying the mismatch region also showed a profile with two dominant bands (Fig. 1), indicating that strain $\mathrm{SB} 1^{\mathrm{T}}$ has at least two different $16 \mathrm{~S}$ rRNA operons within its genome. These two dominant bands were observed in the original sludge and also throughout the serial dilutions that were used to enrich strain $\mathrm{SB}^{\mathrm{T}}{ }^{\text {(Fig. 1). }}$.

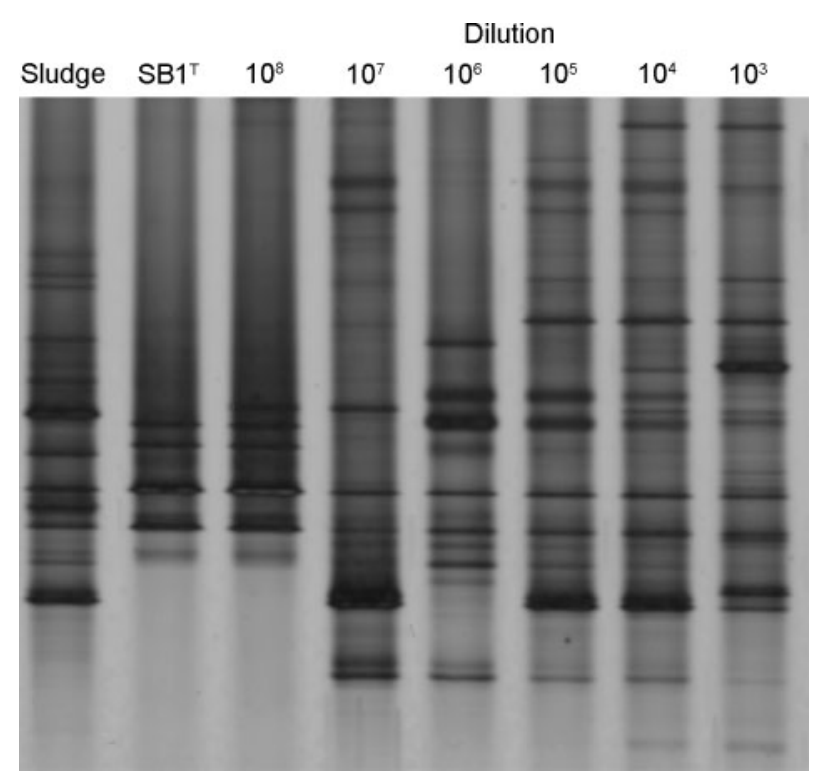

Fig. 1. 16S rRNA gene-based DGGE analysis of the bacterial diversity of the serial dilutions used to enrich strain $\mathrm{SB} 1^{\top}$ (Desulfovibrio paquesii sp. nov.).
This observation, together with the fact that strain $\mathrm{SB} 1^{\mathrm{T}}$ was obtained from a very high $\left(10^{8}\right)$ dilution, indicates it was an abundant sulfate-reducing bacterium at the time of isolation.

16S rRNA gene sequence analysis by using the NCBI BLAST tool (McGinnis \& Madden, 2004) indicated that strain $\mathrm{SB} 1^{\mathrm{T}}$ was most closely related to the sulfate-reducing strain L3 (GenBank accession number EF055876) isolated by Dar et al. (2007) (99\% sequence similarity). Interestingly, strain L3 was found to be a dominant sulfate reducer in an ethanol-fed sulfidogenic THIOPAQ bioreactor. Phylogenetic analysis confirmed strain L3 to be the closest

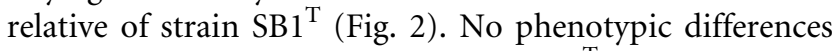
were found between strains $\mathrm{L} 3$ and $\mathrm{SB} 1^{\mathrm{T}}$ based on either substrate utilization or morphological characteristics. A genomic comparison was made by using repetitive enterobacterial palindromic PCR (rep-PCR) as described by Dar et al. (2007); no differences were found in this comparison, indicating that strains $\mathrm{L} 3$ and $\mathrm{SB}^{\mathrm{T}}$ represent the same species. Results of this rep-PCR comparison are shown in Supplementary Fig. S1 in IJSEM Online.

Using the NCBI BLAST tool, the closest recognized relatives to $\mathrm{SB}^{\mathrm{T}}$ were found to be Desulfovibrio indonesiensis DSM $15121^{\mathrm{T}} \quad(89 \%$ sequence similarity) and Desulfovibrio giganteus DSM 4370 (89\%). However, the 16S rRNA gene sequence of Desulfovibrio gigas DSM $1382^{\mathrm{T}}$ (GenBank accession number M34400.1) contained 112 ambiguous nucleotides, which made an accurate phylogenetic comparison impossible with this potentially related organism. Therefore, the 16S rRNA gene of Desulfovibrio gigas DSM $1382^{\mathrm{T}}$ was resequenced (DQ447183). This sequence was aligned with that of strain $\mathrm{SB1} 1^{\mathrm{T}}$ by using the NCBI pairwise alignment BLAST tool, which revealed a similarity of $97.5 \%$. A $16 \mathrm{~S}$ rRNA gene sequence similarity of $97 \%$ is commonly considered as the upper limit for the definition of separate species (Stackebrandt \& Goebel, 1994). Phylogenetic analysis confirmed Desulfovibrio gigas DSM $1382^{\mathrm{T}}$ to be the closest recognized relative of strain $\mathrm{SB}^{\mathrm{T}}$ (Fig. 2). Analysis of the $\mathrm{G}+\mathrm{C}$ content of the genomic DNA of $\mathrm{SB}^{\mathrm{T}}$ was performed at the Deutsche Sammlung von Mikroorganismen und Zellkulturen (DSMZ; Braunschweig, Germany) according to recognized methods (Cashion et al., 1977; Tamaoka \& Komagata, 1984; Mesbah et al., 1989); the DNA G+C content of strain $\mathrm{SB}^{\mathrm{T}}$ was $62.2 \mathrm{~mol} \%$. This is comparable with the value of $60.2 \mathrm{~mol} \%$ found for Desulfovibrio gigas DSM $1382^{\mathrm{T}}$ and falls within the $5 \%$ range normally observed within the same species (Rosselló-Mora \& Amann, 2001).

Genomic DNA-DNA hybridization was performed at the DSMZ according to De Ley et al. (1970) with the modifications suggested by Escara \& Hutton (1980) and Huß et al. (1983). This revealed a level of DNA-DNA relatedness of $56.0 \%$ between strain $\mathrm{SB}^{\mathrm{T}}$ and Desulfovibrio gigas DSM $1382^{\mathrm{T}}$, indicating that the two strains are not related at the species level (Wayne et al., 1987). Differential morphological and physiological characteristics between 


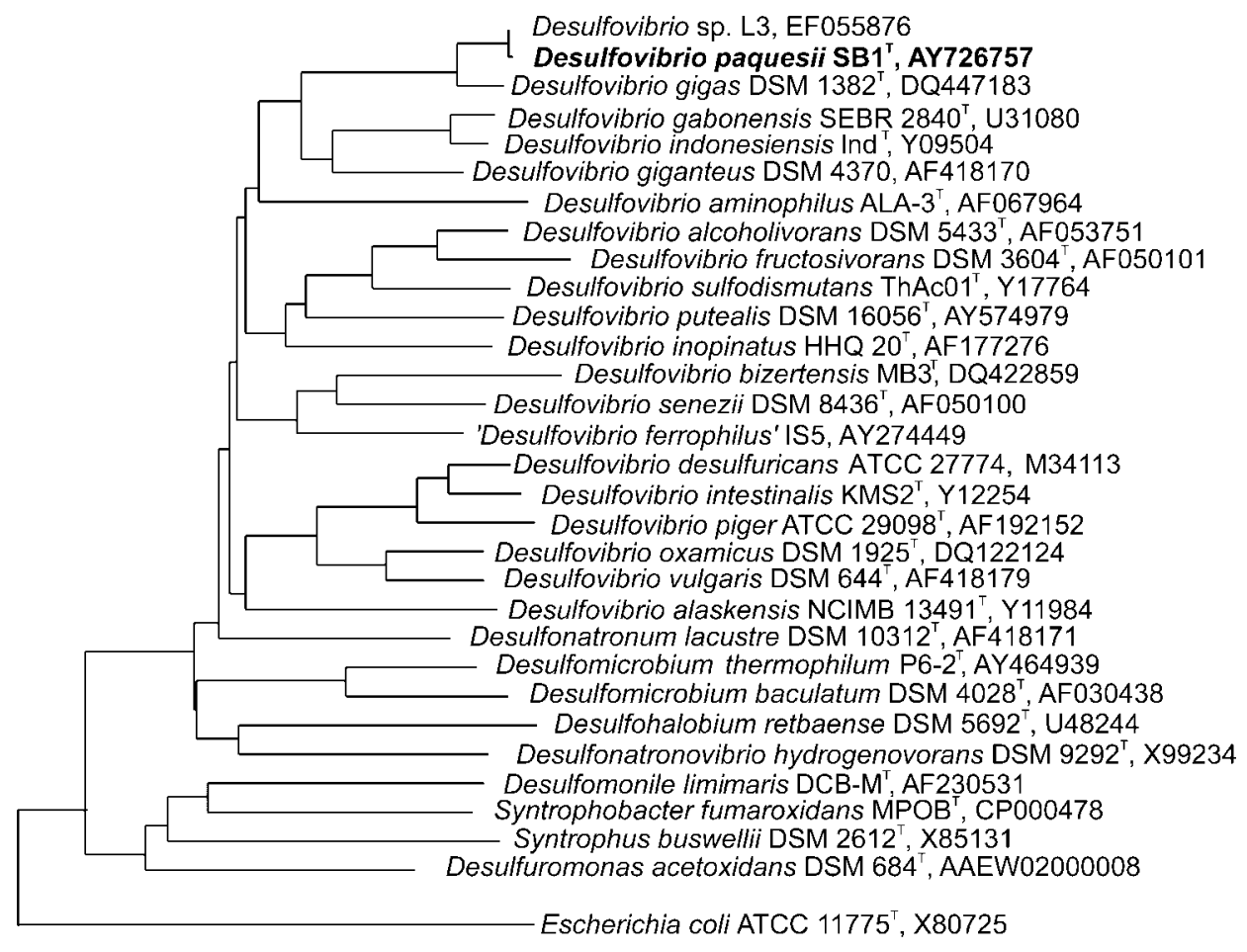

0.10

Fig. 2. Phylogenetic tree based on 16S rRNA gene sequences of selected Deltaproteobacteria. GenBank accession numbers of reference sequences are indicated. E. coli ATCC $11775^{\top}$ was used as an outgroup. Phylogenetic analysis was based on release 93 of the SILVA database (Pruesse et al., 2007). Sequences were aligned by using the ARB software package, with the FastAligner tool, and were checked manually according to secondary structures (Ludwig et al., 2004). A phylogenetic tree was constructed with Felsenstein correction and a filter for Deltaproteobacteria in ARB, according to the neighbour-joining method (E. coli positions 80-1423). Bar, $10 \%$ nucleotide sequence divergence.

strain $\mathrm{SB} 1^{\mathrm{T}}$ and Desulfovibrio gigas DSM $1382^{\mathrm{T}}$ are given in Table 1; other characteristics are given in the species description below. Strain $\mathrm{SB}^{\mathrm{T}}$ showed differences with regard to the utilization of malate, glycerol and pyruvate.
Strain $\mathrm{SB1} 1^{\mathrm{T}}$ also differed from Desulfovibrio gigas DSM $1382^{\mathrm{T}}$ with respect to major cellular fatty acids. Cellular fatty acid composition analysis was performed at the DSMZ according to Kaksonen et al. (2006). Based on the

Table 1. Comparison of the morphological and physiological characteristics of strain $\mathrm{SB}^{\top}{ }^{\top}$ (Desulfovibrio paquesii sp. nov.) and Desulfovibrio gigas DSM $1382^{\top}$

Data for Desulfovibrio gigas DSM $1382^{\mathrm{T}}$ are from Edlund et al. (1985), Esnault et al. (1988), Kremer et al. (1989) and Dar et al. (2007). Tests for utilization of carbon and energy sources were performed in duplicate by using defined medium (Stams et al., 1993) at $37{ }^{\circ} \mathrm{C}$. +, Positive; -, negative. The combination of substrate conversion, product formation and an increase in turbidity was considered to indicate positive growth.

\begin{tabular}{|c|c|c|}
\hline Characteristic & Strain $\mathrm{SB} 1^{\mathrm{T}}$ & D. gigas DSM $1382^{\mathrm{T}}$ \\
\hline Cell size $(\mu \mathrm{m})$ & $1 \times 5-8$ & $0.8-1 \times 6-11$ \\
\hline Major cellular fatty acids & anteiso- $\mathrm{C}_{15: 0}$, iso- $\mathrm{C}_{14: 0}, \mathrm{C}_{18: 1}$ cis 9 & iso- $\mathrm{C}_{15: 0}, \mathrm{C}_{16: 0}$, iso- $\mathrm{C}_{17: 0}$ \\
\hline \multicolumn{3}{|c|}{ Electron donors used for sulfate reduction } \\
\hline Malate $(20 \mathrm{mM})$ & + & - \\
\hline Glycerol (20 mM) & + & - \\
\hline \multicolumn{3}{|l|}{ Fermentative growth with: } \\
\hline Malate $(20 \mathrm{mM})$ & - & + \\
\hline Pyruvate $(20 \mathrm{mM})$ & + & - \\
\hline
\end{tabular}


genotypic and phenotypic data presented, strain $\mathrm{SB}^{\mathrm{T}}$ is considered to represent a novel species of the genus Desulfovibrio, for which the name Desulfovibrio paquesii sp. nov. is proposed.

\section{Description of Desulfovibrio paquesii sp. nov.}

Desulfovibrio paquesii (pa.que'si.i. N.L. gen. n. paquesii of Paques, named after Jos Paques, a Dutch biotechnologist and entrepreneur, in recognition of his contribution to the application of the biological sulfur cycle in anaerobic wastewater treatment).

Cells are Gram-negative, non-spore-forming, motile, vibrio- to spiral-shaped $(1 \times 5-8 \mu \mathrm{m})$, and occur singly or in chains of up to eight cells. Grows between $\mathrm{pH} 6.5$ and 8.5 and at $10-45{ }^{\circ} \mathrm{C}$. Strictly anaerobic; reduces sulfate, sulfite and thiosulfate, producing sulfide. Organic substrates are incompletely oxidized to acetate. Utilizes hydrogen, formate, pyruvate, fumarate, lactate, succinate, malate, ethanol and glycerol as electron donors for sulfate reduction. Acetate, propionate, butyrate, methanol, cysteine and choline do not serve as electron donors. Malate and choline are not used fermentatively. Nitrate is not used as an electron acceptor. Positive for desulfoviridin-type sulfite reductase. Major cellular fatty acids are anteiso- $\mathrm{C}_{15: 0}(38.5 \%)$, iso- $\mathrm{C}_{14: 0}(18.5 \%)$ and $\mathrm{C}_{18: 1}$ cis 9 $(11.3 \%)$. The DNA $\mathrm{G}+\mathrm{C}$ content of the type strain is $62.2 \mathrm{~mol} \%$.

The type strain, $\mathrm{SB} 1^{\mathrm{T}}\left(=\mathrm{DSM} 16681^{\mathrm{T}}=\mathrm{JCM} 14635^{\mathrm{T}}\right)$, was isolated from a sulfidogenic synthesis-gas-fed bioreactor used for remediation of wastewater from a zinc smelter (Budel-Dorplein, The Netherlands).

\section{Acknowledgements}

We would like to thank Ben Abbas for performing the rep-PCR experiment. This research was supported by grant EETK98028 of the Dutch ministries of Economic Affairs, Education, Culture and Sciences, and Housing, Spatial Planning and the Environment.

\section{References}

Boonstra, J., van Lier, J., Janssen, G., Dijkman, H. \& Buisman, C. J. N. (1999). Biological treatment of acid mine drainage. In Biohydrometallurgy and Environment Toward the 21st Century. Process Metallurgy 9B, pp. 559-567. Edited by R. Amils \& A. Ballister. Amsterdam: Elsevier.

Cashion, P., Holder-Franklin, M. A., McCully, J. \& Franklin, M. (1977). A rapid method for the base ratio determination of bacterial DNA. Anal Biochem 81, 461-466.

Dar, S. A., Stams, A. J. M., Kuenen, J. G. \& Muyzer, G. (2007). Coexistence of physiologically similar sulfate-reducing bacteria in a fullscale sulfidogenic bioreactor fed with a single organic electron donor. Appl Microbiol Biotechnol 75, 1463-1472.

De Ley, J., Cattoir, H. \& Reynaerts, A. (1970). The quantitative measurement of DNA hybridization from renaturation rates. Eur $J$ Biochem 12, 133-142.
Edlund, A., Nichols, P. D., Roffey, R. \& White, D. C. (1985). Extractable and lipopolysaccharide fatty acid and hydroxy acid profiles from Desulfovibrio species. J Lipid Res 26, 982-988.

Escara, J. F. \& Hutton, J. R. (1980). Thermal stability and renaturation of DNA in dimethyl sulfoxide solutions: acceleration of the renaturation rate. Biopolymers 19, 1315-1327.

Esnault, G., Caumette, P. \& Garcia, J.-L. (1988). Characterization of Desulfovibrio giganteus sp. nov., a sulfate reducing bacterium isolated from a brackish coastal lagoon. Syst Appl Microbiol 10, 147-151.

Hungate, R. E. (1969). A roll tube method for cultivation of strict anaerobes. Methods Microbiol 3B, 117-132.

Huß, V. A. R., Festl, H. \& Schleifer, K. H. (1983). Studies on the spectrophotometric determination of DNA hybridization from renaturation rates. Syst Appl Microbiol 4, 184-192.

Johnson, D. B. (2000). Biological removal of sulfurous compounds from inorganic wastewaters. In Environmental Technologies, pp. 175206. Edited by P. Lens \& L. Hulshoff Pol. London: International Association on Water Quality.

Kaksonen, A. H., Spring, S., Schumann, P., Kroppenstedt, R. M. \& Puhakka, J. A. (2006). Desulfotomaculum thermosubterraneum sp. nov., a thermophilic sulfate-reducer isolated from an underground mine located in a geothermally active area. Int J Syst Evol Microbiol 56, 2603-2608.

Kremer, D. R., Nienhuis-Kuiper, H. E., Timmer, C. J. \& Hansen, T. A. (1989). Catabolism of malate and related dicarboxylic acids in various Desulfovibrio strains and the involvement of an oxygen-labile NADPH dehydrogenase. Arch Microbiol 151, 34-39.

Lens, P. N. L., Visser, A., Janssen, A. J. H., Hulshoff Pol, L. \& Lettinga, G. (1998). Biotechnological treatment of sulfate-rich wastewaters. Crit Rev Environ Sci Technol 28, 41-88.

Ludwig, W., Strunk, O., Westram, R., Richter, L., Meier, H., Yadhukumar, Buchner, A., Lai, T., Steppi, S. \& other authors (2004). ARB: a software environment for sequence data. Nucleic Acids Res 32, 1363-1371.

McGinnis, S. \& Madden, T. L. (2004). BLAST: at the core of a powerful and diverse set of sequence analysis tools. Nucleic Acids Res 32, W20 W25.

Mesbah, M., Premachandran, U. \& Whitman, W. B. (1989). Precise measurement of the $\mathrm{G}+\mathrm{C}$ content of deoxyribonucleic acid by highperformance liquid chromatography. Int J Syst Bacteriol 39, 159-167.

Oude Elferink, S. J. W. H., Maas, R. N., Harmsen, H. J. M. \& Stams, A. J. M. (1995). Desulforhabdus amnigenus gen. nov. sp. nov. a sulfate reducer isolated from anaerobic granular sludge. Arch Microbiol 164, $119-124$.

Oude Elferink, S. J. W. H., Rinia, H. A., Bruins, M. E., de Vos, W. M. \& Stams, A. J. M. (1997). Detection and quantification of Desulforhabdus amnigenus in anaerobic granular sludge by dot blot hybridization and PCR amplification. J Appl Microbiol 83, 102-110.

Pruesse, E., Quast, C., Knittel, K., Fuchs, B. M., Ludwig, W., Peplies, J. \& Glockner, F. O. (2007). SILVA: a comprehensive online resource for quality checked and aligned ribosomal RNA sequence data compatible with ARB. Nucleic Acids Res 35, 7188-7196.

Roest, K., Heilig, H. G. H. J., Smidt, H., de Vos, W. M., Stams, A. J. M. \& Akkermans, A. D. L. (2005). Community analysis of a full-scale anaerobic bioreactor treating paper mill wastewater. Syst Appl Microbiol 28, 175-185.

Rosselló-Mora, R. \& Amann, R. (2001). The species concept for prokaryotes. FEMS Microbiol Rev 25, 39-67.

Stackebrandt, E. \& Goebel, B. M. (1994). Taxonomic note: a place for DNA-DNA reassociation and $16 \mathrm{~S}$ rRNA sequence analysis in the present species definition in bacteriology. Int J Syst Bacteriol 44, 846-849. 
Stams, A. J. M., Van Dijk, J. B., Dijkema, C. \& Plugge, C. M. (1993). Growth of syntrophic propionate-oxidizing bacteria with fumarate in the absence of methanogenic bacteria. Appl Environ Microbiol 59, 1114-1119.

Tamaoka, J. \& Komagata, K. (1984). Determination of DNA base composition by reversed-phase high-performance liquid chromatography. FEMS Microbiol Lett 25, 125-128.

van Houten, B. H. G. W. (2006). Microbial aspects of synthesis gas fed bioreactors treating sulfate and metal rich wastewaters. $\mathrm{PhD}$ thesis, Wageningen University. van Houten, B. H. G. W., Roest, K., Tzeneva, V. A., Dijkman, H., Smidt, H. \& Stams, A. J. M. (2006). Occurrence of methanogenesis during start-up of a full-scale synthesis gas-fed reactor treating sulfate and metal-rich wastewater. Water Res 40, 553-560.

Wayne, L. G., Brenner, D. J., Colwell, R. R., Grimont, P. A. D., Kandler, O., Krichevsky, M. I., Moore, L. H., Moore, W. E. C., Murray, R. G. E. \& other authors (1987). International Committee on Systematic Bacteriology. Report of the ad hoc committee on reconciliation of approaches to bacterial systematics. Int $J$ Syst Bacteriol 37, 463-464. 